\title{
EHMTI-0213. Does prior craniofacial nociception lead to an increase in cortical excitability?
}

\author{
W Supronsinchai ${ }^{1 *}$, A Srikiatkhachorn ${ }^{2}$ \\ From 4th European Headache and Migraine Trust International Congress: EHMTIC 2014 \\ Copenhagen, Denmark. 18-21 September 2014
}

\section{Introduction}

Attacks of migraine following the intense craniofacial somatosensory activation is observed clinically. The mechanism underlying this phenomenon may involve the trigeminal influence on cortical excitability. Whether or not this evoked attack is specific to craniofacial nociception is still unclear.

\section{Aims}

To compare the effect of prior craniofacial and extracraniofacial nociception on development of cortical spreading depression (CSD) and CSD-evoked cortical hyperemia.

\section{Methods}

Formalin $10 \%(0.1 \mathrm{ml}$.) was subcutaneously injected into the forehead and forepaw of adult male Wistar rats (7 each) in order to induce nociception. Saline of the same volume was given to the control animals. One hour after injection, CSD was induced by application of $3 \mathrm{mg}$ of solid potassium chloride on rat's parietal cortex. The depolarization shift (DC shift) and CSD-evoked changes in cortical blood flow were recorded for one hour.

\section{Results}

Nociceptive activation induced by formalin injection into forehead and forepaw significantly increased the development of CSD and CBF. The number of DC shifts was $12 \pm 2$, and $15 \pm 1$ in the control and facial nociception groups, respectively. Similar pattern was observed in the forepaw nociception group. The number of DC shifts was $12 \pm 2$, and $17 \pm 2$ in the control and forepaw nociception groups, respectively. Characteristics of CSD-

'Department of Physiology Faculty of Dentistry, Chulalongkorn University, Bangkok, Thailand

Full list of author information is available at the end of the article evoked cortical hyperemia were not different comparing between facial and forepaw nociception groups.

\section{Conclusion}

Our findings indicate that acute nociceptive activation can facilitate the development of CSD regardless of site of nociception. These results imply that nociception-evoked cortical hyperexcitability may involve modification of central modulating system and does not specific to trigeminal nociception.

No conflict of interest.

\section{Authors' details}

'Department of Physiology Faculty of Dentistry, Chulalongkorn University, Bangkok, Thailand. ${ }^{2}$ Department of Physiology Faculty of Medicine,

Chulalongkorn University, Bangkok, Thailand.

Published: 18 September 2014

doi:10.1186/1129-2377-15-S1-F25

Cite this article as: Supronsinchai and Srikiatkhachorn: EHMTI-0213. Does prior craniofacial nociception lead to an increase in cortical excitability? The Journal of Headache and Pain 2014 15(Suppl 1):F25.

Submit your manuscript to a SpringerOpen ${ }^{\odot}$ journal and benefit from:

- Convenient online submission

- Rigorous peer review

- Immediate publication on acceptance

- Open access: articles freely available online

- High visibility within the field

- Retaining the copyright to your article

Submit your next manuscript at $>$ springeropen.com

\section{SpringerOpen ${ }^{\circ}$}

(C) 2014 Supronsinchai and Srikiatkhachorn; licensee Springer. This is an Open Access article distributed under the terms of the Creative Commons Attribution License (http://creativecommons.org/licenses/by/2.0), which permits unrestricted use, distribution, and reproduction in any medium, provided the original work is properly cited. 